\title{
The Puzzling Earth
}

\section{Santosh $h^{1,2^{*}}$ and K. Sajeev ${ }^{3}$}

Planet Earth is unique in terms of its dynamic nature driven by the movement of lithospheric plates through what Earth Scientists term as plate tectonics which is the fundamental driver for continent building, life evolution and extinction, natural hazards, as well all the evolution of natural resources and environment. The history of our planet over its 4.6 billion years since birth is mostly shrouded in mystery except for our direct knowledge on ongoing processes from which we attempt to build the jigsaw puzzles of the past. In this special issue of the IISc Journal, we assemble five contributions that address some of the key evidence gathered from the Indian subcontinent and the adjacent Sri Lankan region that provide insights in various Earth processes in relation to the geological evolution through various tectonic processes.

The opening paper by Bose and Dasgupta ${ }^{1}$ focuses on the Eastern Ghats Belt and its implications on the Proterozoic evolution of the Greater Indian landmass. They correlate tectonic cycles involving cratonic blocks of India and East Antarctica in the broad framework of the assembly of the supercontinent Rodinia. The conclude that the Eastern Ghats Belt of India played a pivotal role in the continental amalgamation process and it evolved in tandem with the Central Indian Tectonic Zone and the Aravalli Delhi Mobile Belt.

In the next paper, Silpa and Satish-Kumar ${ }^{6}$ investigate the mafic dyke swarms in the Dharwar Craton to gain insights on the Archean-to-early Paleoproterozoic evolution. They present petrological and geochemical data on dyke rocks from the Western and Eastern Dharwar Cratonic blocks and bring out their distinctions. The authors conclude that the dykes were emplaced prior to the amalgamation of the Western and Eastern Dharwar blocks. They compare their results in a global perspective to understand the global-scale magmatic activity and inter-craton correlations.

Hari et al. $^{2}$ investigate the granitoids from the Phenai Mata Igneous complex in the Deccan Large Igneous Province of central India. They identify contrasting magmatic conditions in the generation of anorogenic (A-type) felsic rocks based on a detailed analysis of the geochemical features of these rocks, the authors fractional crystallization from a basaltic magma, for one suite and crustal reworking or assimilation of crustal components for the second suite. The magmas underwent different degrees of crustal contamination during their ascent and were emplaced at shallow crustal levels.

In the next contribution, Pandey et al. ${ }^{5}$ present results from petrographic and mineral chemical studies on xenoliths in a lamprophyre from the Deccan Province. They correlate the recurrent lamprophyre emplacement in this region to the polychronous nature of Late Cretaceous alkaline magmatism in NW India associated with extensional events linked with the reactivation of the Narmada rift zone.

In the next contribution, Malaviarachchi ${ }^{4}$ provides an over view on the age of magmatism and crustal evolution in Sri Lanka based on U-Pb and $\mathrm{Lu}-\mathrm{Hf}$ isotopes. They identify distinct crustal provinces. The $\mathrm{Lu}-\mathrm{Hf}$ systematics from the Highland Complex record some of the oldest models age of $\sim 3.5 \mathrm{Ga}$ suggesting contribution from older subducted sediments and/or crustal components. The Sri Lankan terrains were juxtaposed at an active continental margin setting associated with two stages of subduction during the amalgamation of the Gondwana supercontinent.

In the final contribution, Lodhi et al. ${ }^{3}$ evaluates the current trends in hyperspectral imaging from different platforms and instruments for various applications. These include mobile platforms, space-borne, airborne, ground-based sensing, unmanned aerial system, and underwater vehicle-based, in relation to Earth Observation.

We hope that the articles assembled in this special issue will provide a glimpse on the various geological and tectonic processes that contributed to the building of the continental and cratonic blocks in the Indian Peninsula and adjacent
${ }^{1}$ China University of Geosciences, Beijing, China.

2 University of Adelaide,

Adelaide, Australia.

${ }^{3}$ Indian Institute

of Science, Bangalore, India.

*santosh@cugb.edu.cn 
regions in the context of understanding the puzzling Earth processes over millions of years.

Published online: 11 November 2018

\section{References}

1. Bose S, Dasgupta S (2018) Eastern Ghats Belt, Grenvillian-age tectonics and the evolution of the Greater Indian Landmass: a critical perspective. J Indian Inst Sci. https:// doi.org/10.1007/s41745-018-0068-2

2. Hari KR, Manu Prasanth MP, Swarnkar V, Vijaya Kumar J, Randive KR (2018) Evidence for the contrasting magmatic conditions in the petrogenesis of A-type granites of Phenai Mata Igneous complex: implications for felsic magmatism in the Deccan large Igneous Province. J Indian Inst Sci. https://doi.org/10.1007/s4174 5-018-0079-z
3. Lodhi V, Chakravarty D, Mitra P (2018) Hyperspectral imaging for earth observation: platforms and instruments. J Indian Inst Sci. https://doi.org/10.1007/s4174 5-018-0070-8

4. Malaviarachchi SPK (2018) Review on age of magmatism and crust formation in Sri Lanka: U-Pb and Lu-Hf isotopic perspectives. J Indian Inst Sci. https://doi. org/10.1007/s41745-018-0069-1

5. Pandey R, Sahoo S, Pandit D, Pandey M, Chalapathi Rao NV (2018) Recurrent lamprophyre magmatism in the Narmada rift zone: petrographic and mineral chemistry evidence from xenoliths in the Eocene Dongargaon lamprophyre, NW Deccan Large Igneous Province, India. J Indian Inst Sci. https://doi.org/10.1007/s4174 5-018-0074-4

6. Silpa AS, Satish-Kumar M (2018) Dyke swarms in the Dharwar Craton: a key to understand the late Archean to early Proterozoic cratonic correlations. J Indian Inst Sci. https://doi.org/10.1007/s41745-018-0090-4
M. Santosh is a Professor at the China University of Geosciences Beijing (China), Professor at the University of Adelaide, Australia, and Emeritus Professor at the Faculty of Science, Kochi University, Japan. He is the Founding Editor of Gondwana Research as well as the founding Secretary General of the International Association for Gondwana Research. Research fields include petrology, fluid inclusions, geochemistry, geochronology, metallogeny and supercontinent tectonics. He is a recipient of National Mineral Award, Outstanding Geologist Award, Thomson Reuters 2012 Research Front Award, Thomson Reuters/Clarivate Highly Cited Researcher 2014, 2015, 2016 and 2017.

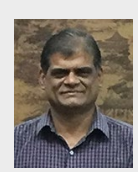

K. Sajeev is an Associate Professor at the Indian Institute of Science, Bangalore (India). He is an Associate Editor of Gondwana Research. Research fields include petrology and geochronology with specific relevance to Precambrian crustal evolution. 